\title{
Emerging aspects of oesophageal and gastro-oesophageal junction cancer histopathology - an update for the surgical oncologist Ewen A Griffiths' ${ }^{1}$, Susan A Pritchard ${ }^{2}$, Nicholas P Mapstone ${ }^{3}$ and Ian M Welch*4
}

\begin{abstract}
Address: ${ }^{1}$ Department of General Surgery, The University Hospitals of Morecambe Bay NHS Trust, Royal Lancaster Infirmary, Ashton Road, Road, Wythenshawe, Manchester, M23 9LT, UK, ${ }^{3}$ Department of Pathology, The University Hospitals of Morecambe Bay NHS Trust, Royal NHS Trust, Wythenshawe Hospital, South Moor Road, Wythenshawe, Manchester, M23 9LT, UK

Email: Ewen A Griffiths - eagriffiths@doctors.org.uk; Susan A Pritchard - susan.pritchard@smuht.nwest.nhs.uk; Nicholas P Mapstone - nicholas.mapstone@rli.mbht.nhs.uk; Ian M Welch* - ian.welch@smuht.nwest.nhs.uk

* Corresponding author
\end{abstract} Lancaster, LA1 4RP, UK, 2Department of Histopathology, South Manchester University Hospitals NHS Trust, Wythenshawe Hospital, South Moor Lancaster Infirmary, Ashton Road, Lancaster, LA1 4RP, UK and ${ }^{4}$ Department of Gastrointestinal Surgery, South Manchester University Hospitals

Published: 2I November 2006

World Journal of Surgical Oncology 2006, 4:82 doi:10.1186/1477-7819-4-82

This article is available from: http://www.wjso.com/content/4/I/82

(c) 2006 Griffiths et al; licensee BioMed Central Ltd.

This is an Open Access article distributed under the terms of the Creative Commons Attribution License (http://creativecommons.org/licenses/by/2.0), which permits unrestricted use, distribution, and reproduction in any medium, provided the original work is properly cited.

\begin{abstract}
Adenocarcinoma of the oesophagus and gastro-oesophageal junction are rapidly increasing in incidence and have a well described sequence of carcinogenesis: the Barrett's metaplasia-dysplasiaadenocarcinoma sequence. During recent years there have been changes in the knowledge surrounding disease progression, cancer management and histopathology specimen reporting. Tumours around the gastro-oesophageal junction (GOJ) pose several specific challenges. Numerous difficulties arise when the existing TNM staging systems for gastric and oesophageal cancers are applied to GOJ tumours. The issues facing the current TNM staging and GOJ tumour classification systems are reviewed in this article. Recent evidence regarding the importance of several histopathologically derived prognostic factors, such as circumferential resection margin status and lymph node metastases, have implications for specimen reporting. With the rising use of multimodal treatments for oesophageal cancer it is important that the response of the tumour to this therapy is carefully documented pathologically. In addition, several controversial and novel areas such as endoscopic mucosal resection, lymph node micrometastases and the sentinel node concept are being studied. We aim to review these aspects, with special relevance to oesophageal and gastro-oesophageal cancer specimen reporting, to update the surgical oncologist with an interest in upper gastrointestinal cancer.
\end{abstract}

\section{Background}

In the Western world, distal oesophageal and gastrooesophageal adenocarcinoma is increasing in incidence faster than any other type of gastrointestinal cancer [1]. During recent years there has been an increase in the understanding of these tumour types and this has implications for the histopathologist and surgical oncologist.
The prognosis for patients with established cancer remains poor. However, with the increasing use of surveillance to monitor the progression of Barrett's oesophagus there is the potential for diagnosis and treatment at an earlier stage. The well defined carcinogenesis sequence of metaplasia-dysplasia-adenocarcinoma lends itself well to surveillance endoscopy. 
There are many studies indicating that hospitals which manage large numbers of patients with upper gastrointestinal cancer have better outcomes [2-4], although not all evidence supports this view [5]. Upper gastrointestinal cancer services in the UK are being streamlined and reorganised with the development of hospital specialist multidisciplinary teams and regional cancer networks $[6,7]$. It is recommended that surgical resection for oesophagogastric cancer is performed in cancer centres serving a population of at least 1 million and containing all necessary multidisciplinary services. Although these studies favouring centralisation have largely assessed factors such as resection rates, postoperative morbidity and mortality and patient survival, there is also evidence that the quality of pathological reporting is improved [2]. Close links between the upper gastrointestinal surgeon, gastroenterologist, medical oncologist, histopathologist and other members of the multidisciplinary team are essential in improving outcomes in oesophageal cancer.

The work load of the specialist gastrointestinal pathologist is increasing, especially in the assessment of oesophageal resection specimens and endoscopic biopsy reporting. There are many reasons for this increase:

- The numbers of patients participating in Barrett's oesophagus surveillance programmes is increasing. A particularly controversial area is the designation of high grade dysplasia (HGD).

- Tumours around the gastro-oesophageal junction, which are rapidly increasing in incidence, pose several specific problems to the histopathologist.

- As with other tumour sites, standardisation and an emphasis on quality and completeness of pathological reporting have become mandatory. There is a need for pathologists to comply with the criteria in the minimum dataset for reporting oesophageal cancer specimens.

- In some units the pathologist has a role in the assessment of the resected specimen immediately after surgical excision.

- Newer evidence on the importance of several histopathological prognostic factors, including circumferential resection margin status and lymph node metastases, will have special implications for specimen reporting.

- With the rising rates of multimodal treatments for oesophageal cancer the pathologist will have an increasing role in documenting the response of the tumour to this therapy.
- The issues of endoscopic mucosal resection (EMR), lymph node micrometastases and the sentinel node concept have the potential to expand the scope of the histopathologist.

We aim to review these aspects, with special relevance to oesophageal and gastro-oesophageal cancer specimen reporting, to update the surgical oncologist with an interest in upper gastrointestinal cancer.

\section{Endoscopic biopsies}

Accurate assessment of endoscopic biopsy material is crucial in the assessment of patients with Barrett's oesophagus, oesophageal epithelial dysplasia and adenocarcinoma. The British Society of Gastroenterology (BSG) has recently published guidelines for the diagnosis and management of Barrett's columnar-lined oesophagus [8]. More biopsies are being examined due to the increase in number of patients enrolled on endoscopic surveillance programmes. Accurate classification into these diagnostic categories often requires multiple biopsies, especially in high-grade dysplasia (HGD). The Seattle group recommend four quadrant biopsies for every $2 \mathrm{~cm}$ interval of Barrett's change identified at screening endoscopy [9]; this is increased to four quadrant biopsies every $1 \mathrm{~cm}$ interval in cases of follow-up of Barrett's dysplasia. A thorough review of the current pathological aspects of these pre-malignant changes is beyond the scope of this review (for recent review see [10]). However, the controversy surrounding Barrett's dysplasia, especially HGD, deserves a mention.

\section{Barrett's dysplasia}

Dysplasia is defined as unequivocal neoplastic transformation of the epithelium, strictly confined within the basement membrane of the gland from which it arises [11]. There is frequent disagreement between the classification of HGD and intra-mucosal carcinoma [12]. The WHO recommend the use of high grade intra-epithelial neoplasia to cover both HGD and carcinoma in-situ to try to increase inter-observer agreement, however in the UK dysplasia is still in use. Changes in the epithelial cells include lack of maturation towards the surface, variation in nuclear size and shape, nucleolar enlargement, increased cytoplasmic ratio, hyperchromasia and presence of abnormal mitoses. Architectural changes seen in dysplasia include stratification of nuclei with loss of the normal basal location. Barrett's dysplasia is classified into either indefinite for dysplasia, low grade dysplasia (LGD) or HGD by the degree of cellular and architectural changes $[13,14]$. A diagnosis of indefinite for dysplasia is made when histological features suggestive of dysplasia are seen but the presence of inflammation makes it impossible to distinguish confidently between reactive changes and true dysplasia. The BSG guidelines recommend prompt fol- 
low-up and treatment of cases of indefinite dysplasia with acid suppression followed by extensive endoscopic biopsies [8]. Further endoscopy and biopsies should then be taken after six months and if all fail to show definite evidence of dysplasia the patient can return to routine follow-up. LGD should be managed by acid suppression for eight to twelve weeks followed by repeat endoscopy and extensive re-biopsy. If the LGD persists surveillance should be six monthly. If regression occurs on two consecutive examinations surveillance intervals may be increased to two to three yearly.

As a consequence of the subtle cytological changes from LGD to HGD, previous studies have shown that there are marked intra-observer and inter-observer variations in the classification of the degree of dysplasia [15]. The clinical application of these studies is to emphasize the need of a second opinion from an experienced gastrointestinal histopathologist in difficult cases, especially when the distinction is clinically important and will change therapeutic management [16]. This may require a further endoscopy for collection of additional material using the 'Seattle' protocol to ensure sufficient tissue for accurate designation is available and to minimise the risk of missing an occult adenocarcinoma [9]. Unfortunately there are at present no reliable immunohistochemical markers available to distinguish between reactive changes and dysplasia. When there is consensus among three pathologists on the designation of LGD, then the progression to HGD or carcinoma appears to be substantial [17].

Appropriate care of patients with HGD in the setting of Barrett's oesophagus relies heavily on the accuracy of reporting the degree of dysplasia [18]. Early studies have shown that HGD was associated with up to a $73 \%$ risk of undetected adenocarcinoma on subsequent oesophagectomy specimens $[19,20]$. There are conflicting results on whether the risk of progression is related to the extent of HGD present. In one study, the risk was unrelated to the amount of HGD present [21]; therefore even a small area should not be discounted. However, in another study multifocal HGD had a higher risk of progression to malignancy than unifocal HGD [22]. This may be due to factors relating to genomic instability and clonal expansion [23].

Treatment options for HGD are controversial and range from intense endoscopic surveillance, endoscopic ablative therapy, EMR and oesophagectomy [24]. In those unfit for surgery endoscopic ablation or EMR should be considered. In Japan, EMR is the standard treatment for early neoplasms but these tend to be squamous cell carcinomas which have many differing characteristics to adenocarcinomas. The recent BSG guidelines recommend oesophagectomy in a specialised unit in patients considered fit for surgery.

\section{Standardisation of oesophageal resection specimen reporting}

The histopathologist has an important role in ensuring quality and a consistent approach to pathological reporting. An accurate histopathology report is essential for providing detailed staging of the primary tumour, elucidating prognostic information and for guiding optimal clinical management decisions. Audit, research, cancer registry data and other epidemiological studies rely heavily on the accuracy of this information. Upper gastrointestinal surgeons and clinicians have demanded an increase in the quality and quantity of information from the pathologist.

The Royal College of Pathologists have published guidelines on the standards of oesophageal resection specimen reporting which include a proforma detailing the Minimum Dataset requirements [25]. A similar 'best practice' report has been published by the Association of Clinical Pathologists (ACP) [26] and the College of American Pathologists has its own guidelines [27]. Despite this guidance the quality of pathological reporting has been variable $[28,29]$. Missing data items from an audit of oesophageal resection specimens reported in 2004 included key data (\% missing) such as tumour differentiation (14\%), proximal margin involvement (17\%), distal margin involvement $(19 \%)$, completeness of resection $(48 \%)$ and circumferential margin involvement (48\%) [29]. It is hoped, as with other cancer types, that the increased use of proformas will increase quality and standardisation of specimen reporting [28]. The centralisation of oesophageal surgery services in one region resulted in a significant improvement in oesophageal resection specimen reporting [2].

\section{The resected specimen: problems around the gastro- oesophageal junction (GOJ)}

Tumours around the gastro-oesophageal junction (GOJ) have become commoner in recent decades $[1,30,31]$ and present particular challenges. Classification systems for GOJ tumours have been devised [32,33], but sadly they have not been widely adopted into routine clinical practice in the UK. Sub-classification is not a part of the current requirements of the Royal College of Pathologists Minimum Dataset for reporting oesophageal cancer [25]. Here a carcinoma is classified as oesophageal if more than half of the tumour is above the gastro-oesophageal junction. Histopathologists sometimes find the distinction between oesophageal and gastric tumours surrounding the gastro-oesophageal junction difficult. This is usually defined endoscopically as the upper limit of the gastric rugal folds. In large tumours the gastro-oesophageal junction may be obliterated making it impossible to comment on whether the tumour is mainly above or below it. In such cases the anatomical site (recognised by the peritoneal reflection at the junction of the oesophagus and 
greater curve of the stomach) of the gastro-oesophageal junction may be of help [26]. The histopathologist may look for the presence of columnar lined oesophagus above the tumour that would be suggestive of an oesophageal origin, especially if associated with dysplasia, or for gastric dysplasia suggesting gastric origin. However, the definition, location and extent of the gastric cardia and GOJ are controversial in much of the medical literature. This can make it harder to compare and contrast previously published studies including different patient populations with heterogeneous tumour types.

The UICC/AJCC classification systems rely on the anatomical location of the epicentre or predominant mass of the tumour to decide whether the tumour is oesophageal or gastric in origin [34]. With the increasing proportion of these cancers, especially types which straddle the GOJ with equal proportions on each side, it has become apparent that this system is inadequate. The Siewert classification system was approved following a consensus conference of the International Society for Diseases of Esophagus (ISDE) meeting in 1995 [35] and is the most widely adopted classification system. GOJ tumours are anatomically classified into three sub-types depending on distance from the cardia, which is defined as the proximal end of the typical longitudinal gastric mucosa folds [33]. According to the authors, there are key differences in epidemiological, clinical and pathological characteristics between these tumour subtypes and the classification system can also aid planning of surgical treatment (Table 1). These tumour sub-types also differ in their predilection for lymph node metastases to the mediastinal and abdominal lymph node stations (Figure 1). Siewert's classification system is recommended for use by the British
Society of Gastroenterology in the published Guidelines for the management of oesophageal and gastric cancer as 'it is uniform, allows data comparison from different centres, and is important for the stratification of patients in prospective studies' [16]. Criticisms of the Siewert system are 1) that it unnecessarily complicates the assessment of these tumours; 2) it is difficult to assign some tumours because of their size and overlapping nature and 3) that some authors prefer to classify distal oesophageal and gastroesophageal junction tumours as one clinical entity as they have found similar distributions of lymph node metastases and survival [36-38].

\section{Problems with the current TNM staging systems}

The existing TNM staging system also has some deficits [39], which include the following:

- It is based primarily on data from patients with squamous cell carcinoma of the middle and upper oesophagus

- There is confusion regarding whether the oesophageal or gastric TNM systems should be used for GOJ tumours

- Lymph node involvement beyond the regional lymph nodes is considered metastatic disease (M1)

- The number of positive lymph nodes has been shown to be a strong prognostic factor by many authors, however, this is not apart of the current TNM system

Currently there is confusion about whether the gastric or oesophageal staging systems should be used for the histological reporting of gastro-oesophageal junction tumours. Due to this confusion a tumour at the GOJ could be clas-

Table I: Tumour around the gastro-oesophageal junction: classification system and principal differences. (Information taken from [33, 42, II0])

\begin{tabular}{|c|c|c|c|}
\hline GOJ subtypes & $\begin{array}{c}\text { Type I (Adenocarcinoma of } \\
\text { distal oesophagus) }\end{array}$ & $\begin{array}{l}\text { Type II (True cardia } \\
\text { carcinoma) }\end{array}$ & $\begin{array}{l}\text { Type III (Sub-cardial } \\
\text { carcinoma) }\end{array}$ \\
\hline Endoscopic criteria & $\begin{array}{l}\text { Tumour mass arises I to } 5 \mathrm{~cm} \\
\text { above the endoscopic cardia }\end{array}$ & $\begin{array}{l}\text { Tumour mass arises } 1 \mathrm{~cm} \text { above to } \\
2 \mathrm{~cm} \text { below the endoscopic cardia }\end{array}$ & $\begin{array}{l}\text { Tumour mass arises } 2 \text { to } 5 \mathrm{~cm} \\
\text { below the area of the endoscopic } \\
\text { cardia }\end{array}$ \\
\hline Differing Characteristics & $\begin{array}{l}\text { - Male predominance } \\
\text { - Arise in association with Barrett's } \\
\text { oesophagus ( } 80 \%) \\
\text { - More likely to have hiatus hernia } \\
\text { or history of GORD }\end{array}$ & $\begin{array}{l}\text { - More similarities to Type III } \\
\text { tumours than Type I } \\
\text { - Barrett's mucosa identified in 10\% }\end{array}$ & $\begin{array}{l}\text { - Barrett's mucosa identified in only } \\
2 \% \\
-60 \% \text { have a diffuse growth pattern } \\
\text { and } 70 \% \text { undifferentiated }\end{array}$ \\
\hline Lymph node metastases & $\begin{array}{l}\text { To mediastinal and abdominal } \\
\text { lymph node stations }\end{array}$ & $\begin{array}{l}\text { Mainly to abdominal lymph node } \\
\text { stations }\end{array}$ & $\begin{array}{l}\text { Mainly to abdominal lymph node } \\
\text { stations }\end{array}$ \\
\hline Precursor lesions & Barrett's oesophagus & $\begin{array}{l}\text { Possible short segment Barrett's } \\
\text { oesophagus or IM at the gastric } \\
\text { cardia }\end{array}$ & $\begin{array}{l}\text { Helicobacter pylori and IM of the } \\
\text { subcardia region }\end{array}$ \\
\hline Optimal surgical treatment & $\begin{array}{l}\text { Transthoracic or transhiatal } \\
\text { oesophagectomy }\end{array}$ & $\begin{array}{l}\text { Controversial; may include either } \\
\text { extended total gastrectomy or } \\
\text { transthoracic or transhiatal } \\
\text { oesophagogastrectomy }\end{array}$ & Extended total gastrectomy \\
\hline
\end{tabular}

IM = intestinal metaplasia, GORD = gastro-esophageal reflux disease 


$\begin{array}{llll}\text { SIEWERT TYPE } & \text { I } & \text { II } & \text { III } \\ \text { Mediastinal stations } & & & \\ \text { 1. Paratracheal } & 4 \% & 0 \% & - \\ \text { 2. Carinal } & 10 \% & 0 \% & - \\ \text { 3. Left bronchial } & 15 \% & 0 \% & - \\ \text { 4. Right bronchial } & 19 \% & 0 \% & - \\ \text { 5. Para-aortic } & 20 \% & 2 \% & - \\ \text { 6. Middle and } & & & \\ \text { 7. lower paraoesophageal } & 55 \% & 5 \% & 3 \%\end{array}$

\section{Abdominal stations}

\section{Right paracardial}

9. Left paracardial

\section{Left gastric}

\section{Lesser curve}

\section{Common hepatic}

\section{Splenic artery}

\section{Coeliac axis}

$\begin{array}{lll}41 \% & 46 \% & - \\ 32 \% & 50 \% & - \\ 60 \% & 65 \% & 24 \% \\ 14 \% & 65 \% & 41 \% \\ 3 \% & 16 \% & 17 \% \\ 6 \% & 30 \% & 28 \% \\ 5 \% & 30 \% & -\end{array}$

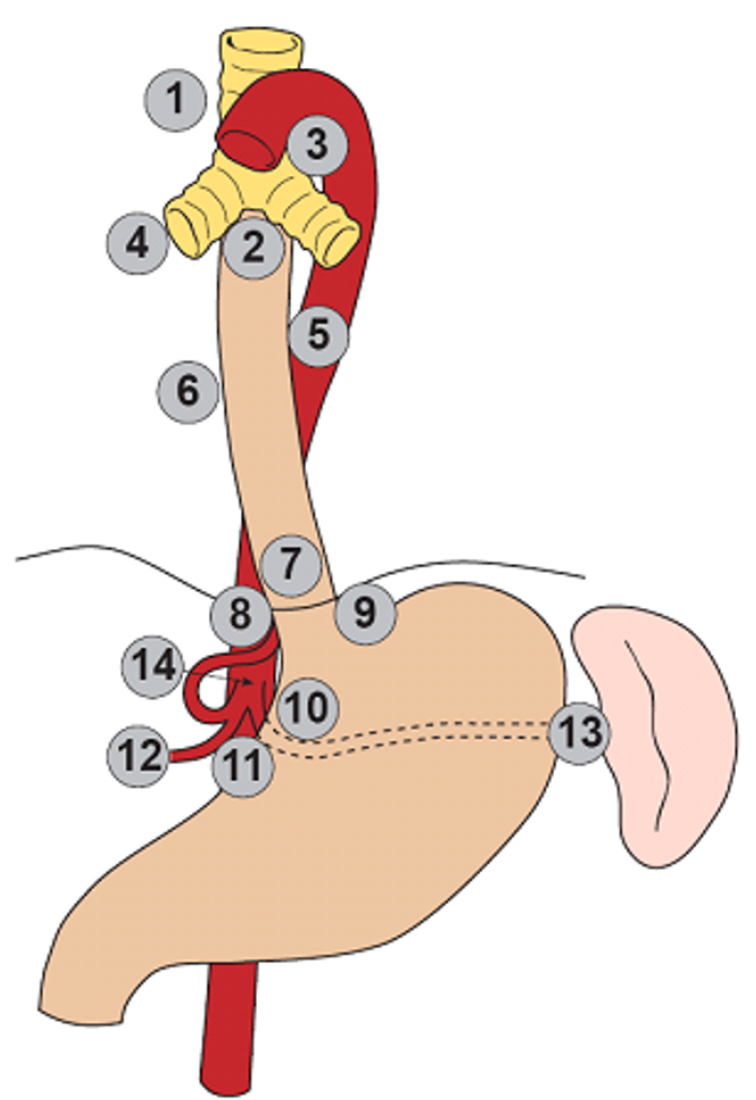

\section{Figure I}

The lymph node stations surrounding the oesophagus and upper stomach are shown. Type I, II and III gastro-oesophageal tumours vary in their predilection for involvement of different lymph node stations in the mediastinum and abdomen. Please note that the information about metastatic spread to the mediastinal lymph nodes in Type III tumours is limited as surgical resection does not normally include these nodes. Information on percentage of lymph node metastases taken from Dresner et al [IIO] and Ichikura et al [I2I].

sified as oesophageal by the surgeon but gastric by the histopathologist or vice versa, especially when cases are not discussed at a preoperative multidisciplinary meeting. Usually, Type I adenocarcinomas are staged as oesophageal cancer and Type III as gastric cancer. Type II adenocarcinomas are staged as oesophageal cancer by some authors and as gastric by others. This is not ideal as there are significant differences between the gastric and oesophageal TNM staging systems in all three TNM categories (Table 2). There are major differences in the $\mathrm{pT}$ stages between the two systems, but the most significant differences are in the $\mathrm{pN}$ staging category. In oesophageal cancer nodal involvement is merely classified as nodal positive ( $\mathrm{pN} 1)$ and nodal negative $(\mathrm{pN} 0)$, irrespective of the number of lymph nodes involved. In comparison, for gastric cancer TNM staging, the $\mathrm{pN}$ category is sub-classified according to the number of involved nodes: $\mathrm{pN} 1$ (16 positive nodes), pN2 (7-15 positive nodes) and pN3
(>15 positive nodes). Metastatic lymph nodes to the coeliac axis are classified as systemic spread (pM1a) in the oesophageal system, whilst they are classified as regional in the gastric staging system. Therefore, the classification of Siewert type II tumours with positive celiac lymph nodes is controversial. Similarly, metastases to the supradiaphragmatic nodes or to the nodes of the lower mediastinum are considered 'non-regional' in gastric cancer, and are classified as distant metastases (pM1) in type II and type III junctional tumours. Consequently there have been calls for tumours around the GOJ to have a separate TNM staging system [40]; however this remains to be designed or approved by the UICC/AJCC.

\section{Histopathological prognostic markers in oesophageal and GOJ cancer}

The most important predictors of prognosis appear to be the overall TNM stage [34], completeness of resection (R 
Table 2: Comparison between the oesophageal and gastric TNM staging [34]

\begin{tabular}{|c|c|c|c|c|}
\hline & & Oesophageal staging & & Gastric staging \\
\hline \multirow[t]{7}{*}{ T Stage } & To & No evidence of primary tumour & TO & No evidence of primary tumour \\
\hline & Tis & Carcinoma in situ & Tis & Carcinoma in situ \\
\hline & TI & Tumour invades lamina propria or submucosa & TI & Tumour invades lamina propria or submucosa \\
\hline & T2 & Tumour invades muscularis propria & $\mathbf{T} 2 \mathbf{a}$ & Tumour invades muscularis propria \\
\hline & T3 & Tumour invades adventitia & $\mathbf{T 2 b}$ & Tumour invades subserosa \\
\hline & T4 & Tumour invades adjacent structures & T3 & $\begin{array}{l}\text { Tumour penetrates serosa (visceral peritoneum) } \\
\text { without invasion of adjacent structures }\end{array}$ \\
\hline & & & T4 & Tumour invades adjacent structures \\
\hline \multirow[t]{5}{*}{ N Stage } & $\mathbf{N X}$ & Regional lymph nodes cannot be assessed & NX & Regional lymph nodes cannot be assessed \\
\hline & No & No regional lymph node metastases & No & No regional lymph node metastases \\
\hline & NI & Regional lymph node metastases & NI & Metastases in I to 6 regional lymph nodes \\
\hline & & & N2 & Metastases in 7 to 15 regional lymph nodes \\
\hline & & & N3 & Metastases in more than 15 regional lymph nodes \\
\hline \multirow[t]{4}{*}{ M Stage } & MX & Distant metastases cannot be assessed & MX & Distant metastases cannot be assessed \\
\hline & Mo & No distant metastases & Mo & No distant metastases \\
\hline & MIa & Metastases to coeliac or cervical lymph nodes & MI & Distant metastases \\
\hline & MIb & Other distant metastases & & \\
\hline
\end{tabular}

classification) [41,42] and the presence of lymph node metastases [43]. Other important histopathological factors are summarised in Table 3. Although newer molecular based markers are being assessed to see if they can be used to predict prognosis, none are in routine clinical use and they are beyond the scope of this article (for recent review see [44]).

Residual disease classification and resection margin involvement The residual tumour classification (Table 4) is one of the strongest prognostic factors after surgical resection $[41,42]$. It is classified into: R0, complete microscopic and macroscopic resection; $\mathrm{R} 1$, residual microscopic disease and R2, residual macroscopic disease (Table 4) [45]. Both the pathologist and the surgeon have roles in defining the $\mathrm{R}$ status during and after surgery.

Table 3: Histopathological prognostic factors after surgical resection of oesophageal cancer

\begin{tabular}{ll}
\hline Factor & Reference \\
\hline Residual (R) tumour classification * & {$[41,42]$} \\
Proximal and distal margin involvement & {$[46,47]$} \\
Circumferential resection margin involvement & {$[50,5 \mathrm{I}, 56]$} \\
Tumour invasion (T stage) & {$[42,68,1 \mathrm{II}, \mathrm{II}]$} \\
Lymph node metastases & {$[42,43,68]$} \\
Vascular invasion & {$[53,113,114]$} \\
Lymphatic vessel invasion (LVI) & {$[6 \mathrm{I}-63]$} \\
Perineural invasion & {$[115]$} \\
Tumour length & {$[43,116]$} \\
Tumour differentiation & {$[117,118]$} \\
Histological subtype & {$[65]$}
\end{tabular}

* R0 complete microscopic and macroscopic resection; RI residual microscopic disease; $R 2$ residual macroscopic disease
The circumferential resection margin (CRM) is defined as the surgically cut surface of the connective tissues that encase the oesophagus. Presence of tumour within $1 \mathrm{~mm}$ of this resection margin is classified as evidence of involvement. Although it has long been established that involvement of the proximal or distal resection margin is a poor prognostic factor [46,47], the relevance of the CRM status has been unclear and few studies have addressed this issue. However, the increased awareness of the CRM status in rectal cancer has inspired investigation in oesophageal cancer. In rectal cancer surgery, the pathological reporting of CRM is important as its status predicts risk of local disease recurrence and reduced survival $[48,49]$. It is routinely reported in all rectal resection specimens and involvement is often an indication for postoperative chemotherapy and/or radiotherapy.

\section{Circumferential resection margin (CRM) involvement and oesophageal cancer reporting (Table 5)}

An initial study by Sagar et al [50] in 1993 assessed 50 patients undergoing oesophagectomy and found that cancer involvement of the CRM was associated with increased risk of local disease recurrence and significantly reduced 2-year survival. More recently, Dexter et al., studied 135 patients who underwent oesophagogastrectomy [51], they included only the patients who had underwent a potentially curative procedure, excluding patients with other margin involvement, T4 tumours, M1a or M1b disease and palliative resections. The rate of CRM involvement in their study was $47 \%$. Survival was significantly reduced in patients with CRM involvement who would have been otherwise considered to have had a potentially curative resection. CRM involvement was also an independent predictor of survival on multivariate analysis. They also observed that when they stratified patients into 
Table 4: Residual (R) tumour classification system [45]

\begin{tabular}{ll}
\hline R Classification & Meaning \\
\hline R0 & Complete resection of microscopic and macroscopic disease \\
RI & Incomplete resection; residual microscopic disease \\
R2 & Incomplete resection; residual macroscopic disease \\
\hline
\end{tabular}

low and high nodal metastatic burden $(<$ or $>25 \%$ involved lymph nodes), the effect of CRM status on survival was more significant in patients with a low ratio of involved metastatic lymph nodes. A recent report suggested that even in patients with T3 tumours and a low percentage of lymph node metastases $(<25 \%)$ there is an improved prognosis if the CRM were negative [52].

In a follow-up study with larger patient numbers carried out by the same group [53], CRM was still a prognostic factor on univariate analysis but lost its significance as an independent prognostic variable. However in this study, the R classification (which included CRM status) was an independent prognostic factor, together with nodal status and vascular invasion.

Not all studies have shown a positive CRM to predict a poor prognosis in oesophageal cancer. Khan et al., [54] observed 329 patients undergoing resection and found no difference in survival between patients with or without CRM involvement. Although the reasons for the difference are not entirely clear, the surgical technique in the Khan study favoured extensive mediastinal dissection. For example, in this study only T3 tumours (tumour invading the adventitia) had evidence of CRM involvement. In the Dexter study there were cases of T2 tumours (tumours invading muscularis propria) involving the CRM [51], suggesting that less radical surgery was performed. In support of this, the study by Khan et al., had the lowest rate of CRM involvement (20\%). Therefore the prognostic impact of CRM status may be related to the completeness of the mediastinal dissection. A similar situation is present in rectal cancer surgery, where the prognostic effect of CRM involvement is lessened following more radical surgical resection [55].

Although Khan et al., questioned whether CRM status should be an essential part of oesophageal resection specimen reporting [54], the majority of studies support the notion that CRM involvement is a significant prognostic factor $[50-53,56]$. Moreover, three of these studies have shown it to be a significant independent predictor of survival on multivariate analysis [51,52,56]. It would seem sensible to continue to record the involvement of the CRM in oesophageal resection specimen reports.

\section{CRM status as a marker of quality of surgery}

It is important that the anatomy of the oesophagus is understood, especially as regards to the surrounding structures in the thorax. The CRM includes the whole circumference at and just above the gastro-oesophageal junction, but more proximally it is concentrated anteriorly and posteriorly with pleura on the lateral aspects. The pleural surfaces are not a true CRM and the significance of tumour involvement at this site is uncertain as there have been no large studies examining this [57]. It can be difficult to identify the pleura on the resected specimen but this difficultly is removed if the surgeon marks the pleural surface or if the fresh resected specimen is seen and discussed together by both surgeon and pathologist.

Table 5: Studies assessing the prognostic impact of CRM status in oesophageal cancer

\begin{tabular}{|c|c|c|c|c|c|c|c|}
\hline Author, Date & No. & Country & Type study & Tumour & $\begin{array}{l}\text { \% CRM } \\
\text { involvement }\end{array}$ & $\begin{array}{l}\text { Significance on } \\
\text { univariate } \\
\text { survival }\end{array}$ & $\begin{array}{l}\text { Significant on } \\
\text { multivariate } \\
\text { survival }\end{array}$ \\
\hline Sagar, 1993 [50] & 50 & UK & $R$ & Adeno, SCC & $40 \%$ & Yes $(p<0.05)$ & Not tested \\
\hline Saha, 200I [56] & 59 & UK & $\mathrm{R}$ & Adeno & Unknown & Yes $(p<0.01)$ & Yes $(p<0.05)$ \\
\hline Dexter, 200I [5I]* & 135 & UK & $P$ & Adeno, SCC & $47 \%$ & Yes $(p<0.015)$ & Yes $(p=0.013)$ \\
\hline Zafirellis, 2002 [53]* & 156 & UK & $P$ & Adeno, SCC & $42 \%$ & Yes $(p<0.0001)$ & Not significant \\
\hline Khan, 2003 [54] & 329 & UK & $R$ & Adeno, SCC & $20 \%$ & No $(p=0.57)$ & Not applicable \\
\hline Roh, 2004 [119] & 59 & Korea & $\mathrm{R}$ & SCC & $44 \%$ & Yes $(p=0.003)$ & Not tested \\
\hline Griffiths, 2006 [52] & 249 & UK & $R$ & Adeno, SCC & $32 \%$ & Yes $(p=0.0001)$ & Yes $(p=0.007)$ \\
\hline
\end{tabular}

$R=$ retrospective,$P=$ prospective, Adeno = adenocarcinoma, $S C C=$ squamous cell carcinoma, ${ }^{*}$ These two studies from the same research group include some of the same patients. 
In rectal surgery, a large intact capsule of mesorectum surrounding the resected cancer specimen has been suggested as a marker of good quality surgery [58,59]. However, there are important anatomical differences between the pelvis and the mediastinum (Figure 2). The oesophagus lacks a serosal layer, so that tumours originating in the

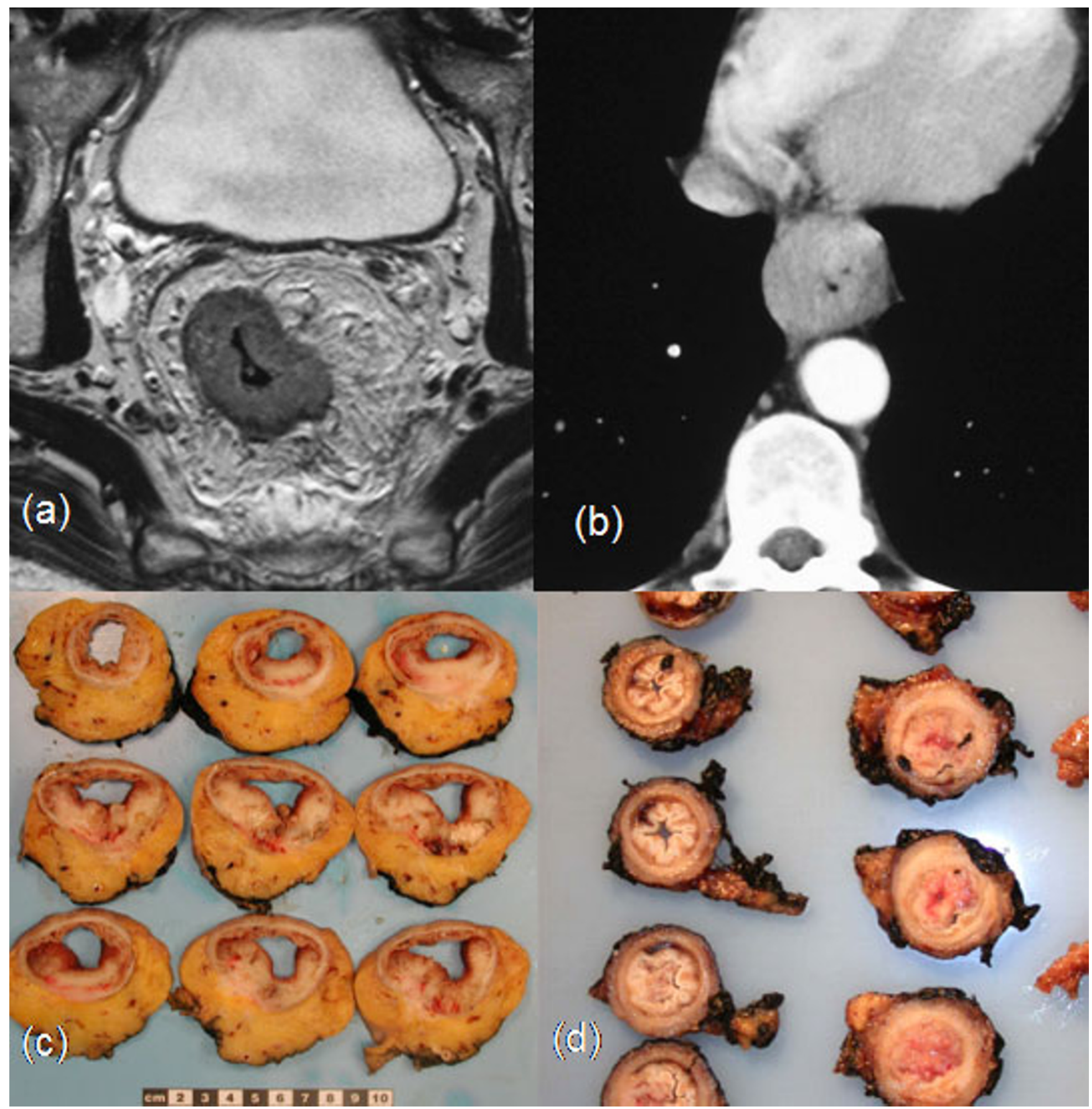

\section{Figure 2}

(a) MRI of the pelvis showing the ample surrounding mesorectal tissue and fascia, in comparison to (b) which shows a CT image of the mediastinum showing how little tissue separates the oesophagus from important unresectable structures such as the aorta and heart. (c) Transverse cut sections of anterior resection specimen for rectal cancer (note how much more surrounding tissue there is compared with the oesophageal specimen) (d) Transverse cut sections of oesophageal resection specimen; this method of sectioning allows direct comparison with the pre-operative staging. 
oesophagus can easily spread into several important structures (pericardium, heart, great vessels, trachea and lung). The majority of these adjacent structures cannot be sacrificed and resected en-bloc. In addition, there is no specific fascial boundary equivalent to the mesorectal or Denonvillier's fascia present in the pelvis. CRM involvement in the oesophageal cancer specimen may therefore be much more a consequence of advanced tumour stage rather than the skill of the surgeon in carrying out a complete resection. Nevertheless, involvement of the CRM may be an indicator of the quality of pre-operative staging. At present most pathologists open oesophagogastric resections longitudinally, with or without pinning out of the fresh specimen, for fixation [26]. This does not allow good comparison with radiological imaging. In rectal tumours transverse slices through the tumour are advocated to allow comparison with MRI. If the quality of oesophagogastric cancer preoperative staging is to be studied transverse slices through the tumour are recommended. The fact that some surgeons remove lymph nodes from the main specimen and submit them separately prevents assessment of the CRM; this should be discouraged. All of the information acquired by separate dissection of the lymph nodes should be available from thorough, although time consuming, macroscopic examination of the fixed specimen. Some feel that separate dissection of the lymph nodes yields a higher lymph node count compared to lymph node harvesting by the histopathologist. However serial slicing with narrow slice width and careful examination of all attached fat, both by palpation and visually, should result in a high lymph node yield. It may be useful to take a macroscopic photograph of the sliced specimen to compare with preoperative imaging.

\section{Serosal invasion}

Serosal invasion is an important prognostic marker in many gastrointestinal malignancies [57]. Gastro-oesophageal junctional tumours may invade the serosal surface of the proximal stomach with or without CRM involvement of the lower oesophagus. Assessment for serosal invasion in this area is included in the oesophageal minimum dataset as there is strong evidence that it is a poor prognostic factor in gastric cancer [57]. However no studies have been performed to prove this is the case in oesophageal tumours [57].

\section{Vascular and lymphatic vessel invasion (LVI)}

Vascular invasion is known to be a strong prognostic factor and is included in the oesophageal minimum dataset. However, it is not included in the gastric minimum dataset [60], which further highlights the differences between the two proformas. Recent evidence has shown that LVI is a strong prognostic factor in both squamous cell carcinomas and adenocarcinomas of the oesophagus [61-63]. In a study focusing on GOJ adenocarcinomas it was found to be an independent prognostic factor [63]. Interestingly in this large study, it appeared to be more prognostic in type II and III GOJ tumours, compared with type I cancers. This adds to the argument that there are biological differences between these tumour types.

\section{Lymph node metastases}

The presence of lymph node metastases is often the most significant independent factor on multivariate analysis $[42,43,64,65]$. However, there is no consensus regarding minimum numbers of lymph nodes to be included in a curative resection for accurate pathological staging or on the sampling technique used. The minimum dataset for oesophageal carcinoma does not comment on how to sample lymph nodes [25]. The minimum dataset for gastric cancers states that the lymph node should be cut through its greatest diameter and one half taken for microscopy [60]. However, this sampling technique has the potential of missing metastatic deposits and it is best practice to examine the whole node microscopically unless it is clearly replaced by tumour [26].

The current (2002) UICC guidelines recommend a minimum examination of 6 lymph nodes to classify a patient N0 [66]. However this falls short of the 15 recommended by the consensus conference of the International Society for Diseases of the Esophagus (ISDE) [67]. As mentioned previously, the current oesophageal staging criteria simply divide patients into lymph node metastases present ( $\mathrm{pN} 1$ ) and lymph node metastases absent ( $\mathrm{pN} 0$ ). This system is crude and does not take into account the total number of resected/examined nodes. There is strong evidence that a lymph node ratio (number of nodes involved/number nodes examined) may be a better system. The prognostic significance of metastatic lymph node ratio has been described in oesophageal adenocarcinoma in Western patients (ratios of 0.2 and 0.3 ) $[42,53,68]$, squamous cell carcinoma in Western patients (ratio of 0.2) [64] and squamous cell carcinoma in Japanese patients (ratio of $0.1)$ [69]. The differences in ratios for each of these studies may reflect the differences in nodal yields obtained from two-field oesophago-gastrectomy for adenocarcinoma and three-field oesophago-gastrectomy for squamous cell carcinoma. Noticeably in all these five studies the lymph node ratio was of greater prognostic significance than the $\mathrm{N}$ stage. As there is no consensus for the exact lymph node ratio, it remains important for the pathologist to accurately report the total number of involved nodes and the total number examined. Also at present only one level of each lymph node is examined microscopically. Further studies researching the benefit of further levels are required [70]; this may potentially yield additional prognostic information, especially in patients who are initially designated pN0 with a low yield of lymph nodes. 
In addition to a pure number based system, nodal involvement in relation to the lymph node capsule (intra or extracapsular) has recently been shown to be strongly prognostic on multivariate survival analysis in oesophagogastric adenocarcinoma $[71,72]$. The 5-year survival for patients with intracapsular nodal involvement was $40.9 \%$ compared with only $18 \%$ with extracapsular involvement [72].

\section{Immunohistochemically detected lymph node micrometastases} Immunohistochemical techniques can identify micrometastases which are missed by standard haematoxylin and eosin staining. Cytokeratin, a component of the cytoskeleton of epithelial cells, is not found in normal nodes enabling monoclonal antibodies to certain cytokeratin markers (such as AE1/AE3) to be used to detect micrometastases. These techniques may detect single tumour cells or cell clusters in lymph nodes that have been staged as tumour free on routine examination. The prognostic outcome of the detection of micrometastases detected by immunohistochemistry is controversial as some studies have found an association with increased risk of tumour recurrence and decreased survival [73-75], but others have not $[76,77]$. The viability of these tumour cells and their potential to form true metastases has been questioned. As such, these techniques remain research tools and are not currently used in daily clinical practice.

\section{Sentinel node concept in oesophageal and GOJ cancer}

The importance and clinical utility of the sentinel node concept has been extensively evaluated in malignant melanoma and breast cancer. It is being evaluated in gastrointestinal cancers [78], including oesophageal cancer. The sentinel node concept relies on two assumptions. Firstly, lymphatic metastases from a solid tumour follow a predictable course and that there is always one node (the 'sentinel node') or group of nodes that is affected first. Secondly, metastases to other lymph nodes or lymph nodes groups cannot occur without involvement of the sentinel node. These assumptions remain to be conclusively proven in the context of oesophagogastric cancer and other confounding factors may exist, such as the possibility of 'skip' metastases [79] and the alteration of lymphatic flow due to 'blocked' nodes.

Initial feasibility studies have been performed in oesophageal cancer $[78,80]$. The principal benefit of the sentinel lymph node concept if validated in oesophageal cancer surgery may be to permit tailoring the extent of the lymphadenectomy. The morbidity from extensive lymphadenectomy can be high; therefore, if the sentinel node is not involved then patients could be spared more extensive surgery. However, the complex and extensive lymphatic drainage of the oesophagus may make this approach problematic and its ultimate role is likely to be limited. In addition, the technique relies on accurate pathological examination of the sentinel node intra-operatively which has its own drawbacks. The exact technique has yet to be defined, but frozen sectioning, touch imprint cytology and rapid immunohistochemistry are being evaluated. Until more extensive high quality prospective studies are performed in oesophageal cancer, the usefulness of the sentinel node concept in this area remains uncertain.

\section{Endoscopic mucosal resection (EMR)}

Endoscopic mucosal resection (EMR) techniques are being increasingly used for treatment and staging of superficial early cancers of the oesophagus, especially in Japan although Western centres are gaining experience $[81,82]$. Although the precise indications for EMR have not been established, in the oesophagus EMR may be curative for small superficial squamous cell carcinomas or adenocarcinomas which are limited to the mucosa or lamina propria [83]. HGD of the oesophagus can also be treated with EMR techniques. The treatment of circumferential lesions is possible, but there is a high risk of subsequent stricture formation. The resected specimen must be carefully examined in its entirety for accurate pathological staging [84] and to allow future audit and preparation of appropriate guidelines on the safe use of this technique. The main problem with EMR is the lack of pathological lymph node staging. The risk of lymph node metastases increases with tumour penetration through the mucosa and submucosa [84]. Based on the Japanese classification of early neoplasia of the oesophagus a more comprehensive staging system than TNM is suggested when reporting such specimens. The recommended staging splits mucosal involvement into three categories (m1: equivalent to HGD with questionable invasion beyond the basement membrane; $\mathrm{m} 2$ : invasion of the lamina propria and $\mathrm{m} 3$ : invasion into but not through the muscularis mucosa) and submucosal involvement into 3 categories ( $\mathrm{sm} 1$ : invasion into the upper third of submucosa; sm2: invasion into the middle third of submucosa and sm3: invasion into the lower third of submucosa). Lymphovascular invasion should be reported if present. As some series report a high rate of incomplete resections with this technique, some authors advocate its use as a diagnostic and staging tool rather than a therapeutic technique [82].

\section{Multimodal therapy and implications for pathological specimen reporting}

Multimodal therapy, in particular neo-adjuvant treatment prior to surgical resection, is increasingly used in oesophageal cancer. The aims of neo-adjuvant chemotherapy, with or without radiotherapy, are to downstage or 'sterilise' the primary to improve the likelihood of complete tumour (R0) resection, reduce tumour recurrence, treat occult micro-metastases and ultimately to improve overall survival. Although there is some evidence from randomised 
controlled trials that neo-adjuvant therapy in addition to surgery can prolong survival [85-88], there remains considerable debate in the literature about the benefits of therapy and the definitive regime has yet to be defined. Other authors have found that multimodal therapy is associated with an increased post-operative mortality $[88,89]$ and morbidity $[90,91]$, especially sepsis related complications, respiratory failure and adult respiratory distress syndrome.

A pathological complete response (CR) occurs in less than $30 \%$ of patients who undergo surgery after preoperative chemotherapy or chemo-radiotherapy [92-94]. Although patients who achieve a CR appear to have a longer overall survival [95-97] these results are mainly from sub-group analysis and should be treated with some caution.

\section{Classifying pathological response to multimodal therapy}

In instances of a potential CR, knowledge of the precise location of the tumour before neo-adjuvant therapy is crucial to direct pathological sampling as the oesophagus may look normal macroscopically. However, the precise number of tumour blocks to take has yet to be clarified and currently is at the discretion of the histopathologist. Various architectural, nuclear and cytoplasmic changes in tumour and non-tumour tissue have been described following neo-adjuvant chemotherapy [98]. In addition, radiotherapy induced changes include fibrosis, telangiectasia of submucosal vessels, bizarre nuclear appearances in tumour and stromal cells and necrosis [99].
Mucin lakes and collections of keratin are considered to represent areas where tumour has been present prior to sterilisation by chemotherapy. Preliminary evidence suggests that prominent acellular mucin pools in patients who have received neo-adjuvant chemotherapy should not be considered evidence of residual disease [100]. Immunohistochemistry using cytokeratin antibodies may be required to identify residual tumour cells not readily seen on haematoxylin and eosin staining.

There are a variety of different grading systems for measuring residual tumour in oesophageal resection specimens after preoperative chemotherapy, with or without radiotherapy (Table 6) [101-103]. The Mandard et al., system [103] would seem to be the most applicable because it assesses residual tumour in relation to background fibrosis, and this has been shown to be important in oesophageal cancer. However, this system was not shown to yield prognostic information in a recent study [98], whereas the residual carcinoma status correlates significantly with prognosis in several retrospective studies $[101,104]$. It also uses a simple system of percentage of residual tumour which is likely to be more reproducible. However, none of these systems have been universally accepted (Table 6).

With the increased interest in multi-modal therapy, however, the classification of pathological response is of increasing importance to the histopathologist and surgeon. Proposals to revise the oesophageal cancer staging

Table 6: Classification systems to grade tumour response to neo-adjuvant chemo-radiotherapy

\begin{tabular}{|c|c|c|}
\hline Reference, Name of classification system & & Details/definition \\
\hline \multirow[t]{5}{*}{ Mandard et al [103]; Tumour regression grade (TRG) } & TRGI & $\begin{array}{l}\text { Complete pathological regression: absence of residual } \\
\text { cancer and fibrosis extending through the layers of the } \\
\text { oesophageal wall }\end{array}$ \\
\hline & TRG2 & $\begin{array}{l}\text { Presence of rare residual cancer cells scattered through } \\
\text { the fibrosis }\end{array}$ \\
\hline & TRG3 & $\begin{array}{l}\text { Increase in the number of residual cancer cells, but fibrosis } \\
\text { still predominant }\end{array}$ \\
\hline & TRG4 & Showing residual cancer outgrowing fibrosis \\
\hline & TRG5 & Absence of regressive changes \\
\hline \multirow[t]{4}{*}{ Chirieac et al [ $10 \mathrm{I}]$; Residual carcinoma status } & 0 & No residual cancer \\
\hline & 1 & $1 \%$ to $10 \%$ residual cancer \\
\hline & 2 & $11 \%-50 \%$ residual cancer \\
\hline & 3 & $>50 \%$ residual cancer \\
\hline \multirow[t]{4}{*}{$\begin{array}{l}\text { General rules for oesophageal cancer proposed by the } \\
\text { Japanese Society for Esophageal Disease [120]* }\end{array}$} & Complete response & $\begin{array}{l}\text { Disappearance of the primary tumour in the postoperative } \\
\text { specimen }\end{array}$ \\
\hline & Partial response & $\begin{array}{l}\text { Microscopic evidence of residual tumour in the } \\
\text { postoperative specimen }\end{array}$ \\
\hline & Stable disease & $\begin{array}{l}\text { Less than } 50 \% \text { decrease or less than a } 25 \% \text { increase in } \\
\text { tumour volume }\end{array}$ \\
\hline & Progressive disease & $\begin{array}{l}\text { No significant change in tumour mass or more than a } 25 \% \\
\text { increase in tumour volume }\end{array}$ \\
\hline
\end{tabular}

*In addition to pathological assessment of the resection specimen, the designation to stable or progressive disease is by re-evaluation of the primary tumour by computed tomography and endoscopy 2 weeks after completion of CRT. 
system to accommodate the pathological response of the tumour following preoperative chemo-radiotherapy have recently been made [104]. The final pathological staging in the cases treated with neo-adjuvant therapy should be prefixed 'y' (for example, ypT2, ypN0, ypM0) [34].

Predictive factors for response to neo-adjuvant chemo-radiotherapy There is great interest in evaluating predictive factors for patient response to neo-adjuvant chemo-radiotherapy. An accurate predictive factor would allow the targeting of therapy to patients who are most likely to achieve a benefit, while those that are unlikely to respond can avoid potentially toxic therapy and receive earlier surgery.

A recent study has shown that patients with signet-ring cell or mucinous histology on pre-treatment biopsies have an improved response and better overall survival when treated with neo-adjuvant chemo-radiotherapy [105]. This study compared 193 patients who were treated with chemo-radiotherapy (5-Flurouracil, cisplatin and taxane with 45 Gy radiotherapy in 25 fractions) followed by surgery with 219 patients who had surgery alone. In the patients who had surgery alone, the overall survival rate was significantly worse if signet-ring or mucinous histology was present. However, in the patients who were treated with chemo-radiotherapy signet-ring or mucinous histology predicted a better overall survival.

More sophisticated molecular techniques have been evaluated on pre-therapeutic biopsies in an attempt to find a good predictive marker. Although, none of these are currently being used in routine clinical practice, the role of the histopathologist in this regard is likely to increase in the future.

\section{Multidisciplinary meetings}

The management of patients with oesophagogastric cancer should be discussed at all key points in the patient journey at specialist multidisciplinary team (MDT) meetings [106]. There is some evidence that MDT discussion is associated with improved patient outcomes in oesophageal cancer [107]. Stephens et al reported a lower operative mortality and improved 5-year survival in $\mathrm{R} 0$ resected patients who were discussed at an MDT compared with patients who underwent R0 resection by independent surgeons [107]. The management of patients with oesophagogastric cancer is complex and involves input from several clinical specialities. A forum in which to review the histological slides may lead to alteration in the final pathological diagnosis [108], either due to specialist pathological review or by additional information provided by the clinician. Regular communication between all specialities at these meetings provides an opportunity to improve and maintain the quality of pathological reporting. Recent evidence has shown that MDT discussion improves the accu- racy of clinical TNM stage allocation and ensures that correct management decisions are applied to patients with gastro-oesophageal cancer [109]. The MDT meeting may also allow the preoperative staging imaging to be compared with the histopathological report or images and this feedback facilitates training, audit and teaching.

\section{Conclusion}

Accurate assessment of endoscopic biopsy material is crucial in the assessment of patients with Barrett's oesophagus. As appropriate care of patients with HGD in the setting of Barrett's oesophagus relies heavily on the accuracy of reporting the degree of dysplasia, standardised methods and guidelines should be followed.

The classification and staging systems for GOJ tumours need to be improved and future research into this area is greatly warranted. A better understanding of the clinical relevance of each classification system for GOJ tumours needs to be achieved before a final recommendation is made. Although the Siewert classification has been shown to have some clinical relevance, other authors have found that it unnecessarily complicates the assessment of these tumours and is fraught with difficulties because of the overlapping nature of tumours in this region. Some authors would argue that instead of three staging systems, only two are required (with a staging system optimised against current criticisms for oesophageal and GOJ tumours and a separate staging system for gastric tumours). Further clinical studies to address these issues are urgently required.

There is already sufficient evidence to confirm that CRM involvement is a marker of poor prognosis in oesophageal cancer. As such, CRM status must continue to be routinely reported. However, our understanding of its full significance is limited compared to the field of rectal cancer where CRM has been extensively studied. For example, studies have been carried out directly comparing histopathological sections with preoperative cross-sectional imaging. In rectal cancer, this information has been used to predict potential CRM involvement prior to surgery and thus the need for neo-adjuvant therapy. In future oesophageal studies, especially prospective trials involving neo-adjuvant therapy or the comparison of different surgical techniques, it is imperative that involvement of the CRM is analysed.

There are exciting new research opportunities in the identification of lymph node micrometastases and sentinel node involvement; however they have yet to be proven clinically useful. There is emerging evidence that the histopathological evaluation of the tumour response to neoadjuvant therapy is prognostically relevant. However, further research studies are required to confirm its role in 
patient management. Although several classification systems have been devised they have yet to be agreed for routine clinical use. A standardised classification system for the assessment of residual tumour burden after neo-adjuvant therapy will need to be agreed and ideally adopted internationally.

\section{Conflict of interests}

The author(s) declare that they have no competing interests.

\section{Authors' contributions}

EG conceived of the original manuscript idea, performed the literature search and wrote the first draft. SP, NM and IW revised subsequent versions of the manuscript for intellectual content. All authors read and approved the final manuscript.

\section{Acknowledgements}

The authors thank the staff of the Medical Illustration Department, Christie Hospital, Manchester for producing the illustration in Figure I.

\section{References}

I. Blot WJ, Devesa SS, Kneller RW, Fraumeni JF Jr.: Rising incidence of adenocarcinoma of the esophagus and gastric cardia. Jama |99|, 265(10): | 287-| 289.

2. Branagan G, Davies N: Early impact of centralization of oesophageal cancer surgery services. $\mathrm{Br} J$ Surg 2004, 91(12): 1630-1632.

3. Lerut T, Nafteux P, Moons J, Coosemans W, Decker G, De Leyn P, Van Raemdonck D: Quality in the surgical treatment of cancer of the esophagus and gastroesophageal junction. Eur J Surg Oncol 2005, 3 I (6):587-594.

4. Metzger R, Bollschweiler E, Vallbohmer D, Maish M, DeMeester TR Holscher $\mathrm{AH}$ : High volume centers for esophagectomy: what is the number needed to achieve low postoperative mortality? Dis Esophagus 2004, I 7(4):3 I0-3 I4.

5. Gillison EW, Powell J, McConkey CC, Spychal RT: Surgical workload and outcome after resection for carcinoma of the oesophagus and cardia. Br J Surg 2002, 89(3):344-348.

6. Guidance on Commissioning Cancer Services: Improving Outcomes in Upper Gastrointestinal Cancers. London , Department of Health; 200I.

7. Melville A, Morris E, Forman D, Eastwood A: Management of upper gastrointestinal cancers. Qual Health Care 200I, I 0(I):57-64.

8. Guidelines for the diagnosis and management of Barrett's columnar-lined oesophagus. British Society of Gastroenterology; 2005.

9. Levine DS, Haggitt RC, Blount PL, Rabinovitch PS, Rusch VW, Reid B]: An endoscopic biopsy protocol can differentiate high-grade dysplasia from early adenocarcinoma in Barrett's esophagus. Gastroenterology 1993, I 05( I):40-50.

10. Flejou JF: Barrett's oesophagus: from metaplasia to dysplasia and cancer. Gut 2005, 54 Suppl I:i6-12.

II. Riddell RH, Goldman H, Ransohoff DF, Appelman HD, Fenoglio CM, Haggitt RC, Ahren C, Correa P, Hamilton SR, Morson BC, et al.: Dysplasia in inflammatory bowel disease: standardized classification with provisional clinical applications. Hum Pathol 1983, I 4( I I):931-968.

12. Ormsby AH, Petras RE, Henricks WH, Rice TW, Rybicki LA, Richter JE, Goldblum JR: Observer variation in the diagnosis of superficial oesophageal adenocarcinoma. Gut 2002, 5 I (5):67I-676.

13. Robert ME: Defining dysplasia in Barrett esophagus. J Clin Gastroenterol 2003, 36(5 Suppl):S19-25; discussion S26-8.

14. Schlemper RJ, Riddell RH, Kato Y, Borchard F, Cooper HS, Dawsey SM, Dixon MF, Fenoglio-Preiser CM, Flejou JF, Geboes K, Hattori T, Hirota T, Itabashi M, Iwafuchi M, Iwashita A, Kim YI, Kirchner T,
Klimpfinger M, Koike M, Lauwers GY, Lewin KJ, Oberhuber G, Offner $F$, Price AB, Rubio CA, Shimizu M, Shimoda T, Sipponen P, Solcia E, Stolte $M$, Watanabe $H$, Yamabe H: The Vienna classification of gastrointestinal epithelial neoplasia. Gut 2000, 47(2):25I-255.

15. Montgomery E, Bronner MP, Goldblum JR, Greenson JK, Haber MM, Hart J, Lamps LW, Lauwers GY, Lazenby AJ, Lewin DN, Robert ME, Toledano AY, Shyr Y, Washington K: Reproducibility of the diagnosis of dysplasia in Barrett esophagus: a reaffirmation. Hum Pathol 200I, 32(4):368-378.

16. Allum WH, Griffin SM, Watson A, Colin-Jones D: Guidelines for the management of oesophageal and gastric cancer. Gut 2002, 50 Suppl 5:v1-23.

17. Skacel M, Petras RE, Gramlich TL, Sigel JE, Richter JE, Goldblum JR: The diagnosis of low-grade dysplasia in Barrett's esophagus and its implications for disease progression. Am J Gastroenterol 2000, 95( 1 2):3383-3387.

18. Schnell TG, Sontag SJ, Chejfec G, Aranha G, Metz A, O'Connell S, Seidel UJ, Sonnenberg A: Long-term nonsurgical management of Barrett's esophagus with high-grade dysplasia. Gastroenterology 200।, I 20(7): I607-1619.

19. Edwards MJ, Gable DR, Lentsch AB, Richardson JD: The rationale for esophagectomy as the optimal therapy for Barrett's esophagus with high-grade dysplasia. Ann Surg 1996, 223(5):585-9; discussion 589-91.

20. Rice TW, Falk GW, Achkar E, Petras RE: Surgical management of high-grade dysplasia in Barrett's esophagus. Am J Gastroenterol 1993, 88(I I): 1832-1836.

21. Dar MS, Goldblum JR, Rice TW, Falk GW: Can extent of high grade dysplasia in Barrett's oesophagus predict the presence of adenocarcinoma at oesophagectomy? Gut 2003, 52(4):486-489.

22. Buttar NS, Wang KK, Sebo TJ, Riehle DM, Krishnadath KK, Lutzke LS, Anderson MA, Petterson TM, Burgart LJ: Extent of high-grade dysplasia in Barrett's esophagus correlates with risk of adenocarcinoma. Gastroenterology 200I, I20(7): I630-I639.

23. Weston AP, Badr AS, Hassanein RS: Prospective multivariate analysis of clinical, endoscopic, and histological factors predictive of the development of Barrett's multifocal high-grade dysplasia or adenocarcinoma. Am J Gastroenterol 1999, 94(I 2):34I3-34I9.

24. Al-Kasspooles MF, Hill HC, Nava HR, Smith JL, Douglass HO, Gibbs JF: High-grade dysplasia within Barrett's esophagus: controversies regarding clinical opinions and approaches. Ann Surg Oncol 2002, 9(3):222-227.

25. Mapstone NP: Minimum dataset for oesophageal carcinoma histopathology reports. London, Royal College of Pathologists; 1998.

26. Ibrahim NB: ACP. Best Practice No 155. Guidelines for handling oesophageal biopsies and resection specimens and their reporting. J Clin Pathol 2000, 53(2):89-94.

27. Lee RG, Compton CC: Protocol for the examination of specimens removed from patients with esophageal carcinoma. A basis for checklists. The Cancer Committee, College of American Pathologists, and the Task Force on the Examination of Specimens From Patients With Esophageal Cancer. Arch Pathol Lab Med 1997, I 2 I(9):925-929.

28. Burroughs SH, Biffin AH, Pye JK, Williams GT: Oesophageal and gastric cancer pathology reporting: a regional audit. J Clin Pathol 1999, 52(6):435-439.

29. King PM, Blazeby JM, Gupta J, Alderson D, Moorghen M: Upper gastrointestinal cancer pathology reporting: a regional audit to compare standards with minimum datasets. J Clin Pathol 2004, 57(7):702-705

30. Devesa SS, Blot WJ, Fraumeni JF Jr.: Changing patterns in the incidence of esophageal and gastric carcinoma in the United States. Cancer 1998, 83( 1 0):2049-2053.

31. Devesa SS, Fraumeni JF Jr.: The rising incidence of gastric cardia cancer. J Natl Cancer Inst 1999, 9 I(9):747-749.

32. Dolan K, Sutton R, Walker SJ, Morris Al, Campbell F, Williams EM: New classification of oesophageal and gastric carcinomas derived from changing patterns in epidemiology. $\mathrm{Br} J$ Cancer 1999, 80(5-6):834-842.

33. Siewert JR, Feith M, Stein HJ: Biologic and clinical variations of adenocarcinoma at the esophago-gastric junction: relevance of a topographic-anatomic subclassification. J Surg Oncol 2005 90(3): 139-46; discussion 146. 
34. Sobin LH: International Union Against Cancer (UICC): TNM Classification of Malignant Tumours. 6th edition. New York, Wiley-Liss; 2002.

35. Siewert JR, Stein HJ: Classification of adenocarcinoma of the oesophagogastric junction. Br J Surg 1998, 85( I I): I457-I459.

36. Wijnhoven BP, Siersema PD, Hop WC, van Dekken H, Tilanus HW: Adenocarcinomas of the distal oesophagus and gastric cardia are one clinical entity. Rotterdam Oesophageal Tumour Study Group. Br J Surg 1999, 86(4):529-535.

37. Ellis FH Jr., Heatley GJ, Balogh K: Proposal for improved staging criteria for carcinoma of the esophagus and cardia. Eur J Cardiothorac Surg 1997, 12(3):36I-4; discussion 364-5.

38. van de Ven C, De Leyn P, Coosemans W, Van Raemdonck D, Lerut $\mathrm{T}$ : Three-field lymphadenectomy and pattern of lymph node spread in T3 adenocarcinoma of the distal esophagus and the gastro-esophageal junction. Eur J Cardiothorac Surg 1999, I5(6):769-773.

39. Lagarde SM, ten Kate FJ, Reitsma JB, Busch OR, van Lanschot JJ: Prognostic factors in adenocarcinoma of the esophagus or gastroesophageal junction. J Clin Oncol 2006, 24(26):4347-4355.

40. de Manzoni G, Pedrazzani C, Verlato G, Roviello F, Pasini F, Pugliese $\mathrm{R}$, Cordiano C: Comparison of old and new TNM systems for nodal staging in adenocarcinoma of the gastro-oesophagea junction. Br j Surg 2004, 91 (3):296-303.

41. Hofstetter W, Swisher SG, Correa AM, Hess K, Putnam JB Jr., Ajani JA, Dolormente M, Francisco R, Komaki RR, Lara A, Martin F, Rice DC, Sarabia AJ, Smythe WR, Vaporciyan AA, Walsh GL, Roth JA: Treatment outcomes of resected esophageal cancer. Ann Surg 2002, 236(3):376-84; discussion 384-5.

42. Siewert JR, Feith M, Werner M, Stein HJ: Adenocarcinoma of the esophagogastric junction: results of surgical therapy based on anatomical/topographic classification in I,002 consecutive patients. Ann Surg 2000, 232(3):353-36I.

43. Eloubeidi MA, Desmond R, Arguedas MR, Reed CE, Wilcox CM: Prognostic factors for the survival of patients with esophageal carcinoma in the U.S.: the importance of tumor length and lymph node status. Cancer 2002, 95(7): |434-| 443.

44. Vallbohmer D, Lenz HJ: Predictive and prognostic molecular markers in outcome of esophageal cancer. Diseases of the Esophagus 2006, 19(6):425-432.

45. Hermanek $P$, Wittekind $C$ : The pathologist and the residual tumor (R) classification. Pathol Res Pract 1994, I 90(2): I I 5- I 23.

46. Law S, Arcilla C, Chu KM, Wong J: The significance of histologically infiltrated resection margin after esophagectomy for esophageal cancer. Am J Surg 1998, 176(3):286-290.

47. Mulligan ED, Dunne B, Griffin M, Keeling N, Reynolds JV: Margin involvement and outcome in oesophageal carcinoma: a 10 year experience in a specialist unit. Eur J Surg Oncol 2004 30(3):313-317.

48. Adam IJ, Mohamdee MO, Martin IG, Scott N, Finan PJ, Johnston D, Dixon MF, Quirke P: Role of circumferential margin involvement in the local recurrence of rectal cancer. Lancet 1994, 344(8924):707-7।I

49. Wibe A, Rendedal PR, Svensson E, Norstein J, Eide TJ, Myrvold HE, Soreide O: Prognostic significance of the circumferential resection margin following total mesorectal excision for rectal cancer. Br J Surg 2002, 89(3):327-334

50. Sagar PM, Johnston D, McMahon MJ, Dixon MF, Quirke P: Significance of circumferential resection margin involvement after oesophagectomy for cancer. Br J Surg I993, 80(II):I386-I388.

5I. Dexter SP, Sue-Ling H, McMahon MJ, Quirke P, Mapstone N, Martin IG: Circumferential resection margin involvement: an independent predictor of survival following surgery for oesophageal cancer. Gut 200I, 48(5):667-670.

52. Griffiths EA, Brummell Z, Gorthi G, Pritchard SA, Welch IM: The prognostic value of circumferential resection margin involvement in oesophageal malignancy. Eur J Surg Oncol 2006, 32(4):4|3-4| 9 .

53. Zafirellis K, Dolan K, Fountoulakis A, Dexter SP, Martin IG, Sue-Ling $\mathrm{HM}$ : Multivariate analysis of clinical, operative and pathologic features of esophageal cancer: who needs adjuvant therapy? Dis Esophagus 2002, I5(2): 155-159.

54. Khan OA, Fitzgerald JJ, Soomro I, Beggs FD, Morgan WE, Duffy JP. Prognostic significance of circumferential resection margin involvement following oesophagectomy for cancer. $\mathrm{Br} / \mathrm{Can}$ cer 2003, 88(10): I549-1552.
55. Merchant NB, Guillem JG, Paty PB, Enker WE, Minsky BD, Quan SH, Wong D, Cohen AM: T3NO rectal cancer: results following sharp mesorectal excision and no adjuvant therapy. J Gastrointest Surg 1999, 3(6):642-647.

56. Saha S, Dehn TC: Ratio of invaded to removed lymph nodes as a prognostic factor in adenocarcinoma of the distal esophagus and esophagogastric junction. Dis Esophagus 200I, 14(1):32-36.

57. Ludeman L, Shepherd NA: Serosal involvement in gastrointestinal cancer: its assessment and significance. Histopathology 2005, 47(2): |23-|3|

58. Birbeck KF, Macklin CP, Tiffin NJ, Parsons W, Dixon MF, Mapstone NP, Abbott CR, Scott N, Finan PJ, Johnston D, Quirke P: Rates of circumferential resection margin involvement vary between surgeons and predict outcomes in rectal cancer surgery. Ann Surg 2002, 235(4):449-457.

59. Nagtegaal ID, van Krieken JH: The role of pathologists in the quality control of diagnosis and treatment of rectal canceran overview. Eur J Cancer 2002, 38(7):964-972.

60. Dixon MF: Minimum dataset for gastric cancer histopathology reports. In Standards and minimum datasets for reporting cancers London, Royal College of Pathologists; 2000.

6I. Watanabe M, Kuwano H, Araki K, Kawaguchi H, Saeki H, Kitamura K, Ohno S, Sugimachi K: Prognostic factors in patients with submucosal carcinoma of the oesophagus. Br J Cancer 2000, 83(5):609-6|3.

62. Brucher BL, Stein HJ, Werner M, Siewert JR: Lymphatic vessel invasion is an independent prognostic factor in patients with a primary resected tumor with esophageal squamous cell carcinoma. Cancer 200I, 92(8):2228-2233.

63. von Rahden BH, Stein HJ, Feith M, Becker K, Siewert JR: Lymphatic vessel invasion as a prognostic factor in patients with primary resected adenocarcinomas of the esophagogastric junction. I Clin Oncol 2005, 23(4):874-879.

64. Roder JD, Busch R, Stein HJ, Fink U, Siewert JR: Ratio of invaded to removed lymph nodes as a predictor of survival in squamous cell carcinoma of the oesophagus. $\mathrm{Br}$ 」 Surg 1994, $8 I(3): 4 I 0-4 \mid 3$

65. Siewert JR, Stein HJ, Feith M, Bruecher BL, Bartels H, Fink U: Histologic tumor type is an independent prognostic parameter in esophageal cancer: lessons from more than I,000 consecutive resections at a single center in the Western world. Ann Surg 200I, 234(3):360-7; discussion 368-9.

66. TNM Supplement: A Commentary on Uniform Use. 3rd Edition edition. Edited by: Wittekind C GFHRVPSLHHDE. Wiley-Liss; 2003.

67. Fumagilli U: Resective surgery for cancer of thoracic esophagus. Results of a consensus conference of the International Society for Diseases of the Esophagus. Dis Esophagus 1996, 9 (Suppl. I):30-38

68. Holscher AH, Bollschweiler E, Bumm R, Bartels $\mathrm{H}$, Hofler H, Siewert JR: Prognostic factors of resected adenocarcinoma of the esophagus. Surgery 1995, I I 8(5):845-855.

69. Tachibana M, Dhar DK, Kinugasa S, Kotoh T, Shibakita M, Ohno S, Masunaga R, Kubota $H$, Nagasue N: Esophageal cancer with distant lymph node metastasis: prognostic significance of metastatic lymph node ratio. J Clin Gastroenterol 2000, 3 I (4):3 I 8-322.

70. Verrill C, Carr NJ, Wilkinson-Smith E, Seel EH: Histopathological assessment of lymph nodes in colorectal carcinoma: does triple levelling detect significantly more metastases? J Clin Pathol 2004, 57(II): II65-1167.

7I. Lagarde SM, ten Kate FJ, de Boer DJ, Busch OR, Obertop H, van Lanschot J]: Extracapsular lymph node involvement in node-positive patients with adenocarcinoma of the distal esophagus or gastroesophageal junction. Am J Surg Pathol 2006, 30(2): $17 \mid-176$.

72. Lerut T, Coosemans W, Decker G, De Leyn P, Ectors N, Fieuws S, Moons J, Nafteux P, Van Raemdonck D: Extracapsular lymph node involvement is a negative prognostic factor in T3 adenocarcinoma of the distal esophagus and gastroesophageal junction. J Thorac Cardiovasc Surg 2003, I 26(4): I I I I- I I 28.

73. Heeren PA, Kelder W, Blondeel I, van Westreenen HL, Hollema H, Plukker JT: Prognostic value of nodal micrometastases in patients with cancer of the gastro-oesophageal junction. Eur J Surg Oncol 2005, 3 I (3):270-276. 
74. Izbicki JR, Hosch SB, Pichlmeier U, Rehders A, Busch C, Niendorf A, Passlick B, Broelsch CE, Pantel K: Prognostic value of immunohistochemically identifiable tumor cells in lymph nodes of patients with completely resected esophageal cancer. $N$ Engl J Med 1997, 337(17): I I88-I I94.

75. Komukai S, Nishimaki T, Watanabe H, Ajioka Y, Suzuki T, Hatakeyama K: Significance of immunohistochemically demonstrated micrometastases to lymph nodes in esophageal cancer with histologically negative nodes. Surgery 2000, I 27( I):40-46.

76. Sato F, Shimada Y, Li Z, Watanabe G, Maeda M, Imamura M: Lymph node micrometastasis and prognosis in patients with oesophageal squamous cell carcinoma. $\mathrm{Br} J$ Surg 200I, 88(3):426-432.

77. Nakamura T, Ide H, Eguchi R, Hayashi K, Ota M, Takasaki K: Clinical implications of lymph node micrometastasis in patients with histologically node-negative (pNo) esophageal carcinoma. J Surg Oncol 2002, 79(4):224-229.

78. Lamb PJ, Griffin SM, Burt AD, Lloyd J, Karat D, Hayes N: Sentinel node biopsy to evaluate the metastatic dissemination of oesophageal adenocarcinoma. Br J Surg 2005, 92(I):60-67.

79. Hosch SB, Stoecklein NH, Pichlmeier U, Rehders A, Scheunemann P, Niendorf A, Knoefel WT, Izbicki JR: Esophageal cancer: the mode of lymphatic tumor cell spread and its prognostic significance. J Clin Oncol 2001, I9(7): 1970-1975.

80. Burian M, Stein HJ, Sendler A, Piert M, Nahrig J, Feith M, Siewert JR: Sentinel node detection in Barrett's and cardia cancer. Ann Surg Oncol 2004, I I (3 Suppl):255S-8S.

81. Barr H, Stone N, Rembacken B: Endoscopic therapy for Barrett's oesophagus. Gut 2005, 54(6):875-884.

82. Hull MJ, Mino-Kenudson M, Nishioka NS, Ban S, Sepehr A, Puricelli W, Nakatsuka L, Ota S, Shimizu M, Brugge WR, Lauwers GY: Endoscopic mucosal resection: an improved diagnostic procedure for early gastroesophageal epithelial neoplasms. Am J Surg Pathol 2006, 30(I): II4-II8.

83. Soetikno R, Kaltenbach T, Yeh R, Gotoda T: Endoscopic mucosal resection for early cancers of the upper gastrointestinal tract. J Clin Oncol 2005, 23(20):4490-4498.

84. Vieth M, Stolte M: Pathology of early upper GI cancers. Best Pract Res Clin Gastroenterol 2005, I 9(6):857-869.

85. Surgical resection with or without preoperative chemotherapy in oesophageal cancer: a randomised controlled trial. Lancet 2002, 359(9319): I727-1733.

86. Naunheim KS, Petruska PJ, Roy TS, Schlueter JM, Kim H, Baue AE: Multimodality therapy for adenocarcinoma of the esophagus. Ann Thorac Surg 1995, 59(5): I085-90; discussion I090-I.

87. Vogel SB, Mendenhall WM, Sombeck MD, Marsh R, Woodward ER: Downstaging of esophageal cancer after preoperative radiation and chemotherapy. Ann Surg 1995, $221(6)$ :685-93; discussion 693-5.

88. Walsh TN, Noonan N, Hollywood D, Kelly A, Keeling N, Hennessy TP: A comparison of multimodal therapy and surgery for esophageal adenocarcinoma. N Engl J Med 1996, 335(7): 462-467.

89. Bailey SH, Bull DA, Harpole DH, Rentz JJ, Neumayer LA, Pappas TN, Daley J, Henderson WG, Krasnicka B, Khuri SF: Outcomes after esophagectomy: a ten-year prospective cohort. Ann Thorac Surg 2003, 75(I):217-22; discussion 222.

90. Abou-Jawde RM, Mekhail T, Adelstein DJ, Rybicki LA, Mazzone PJ, Caroll MA, Rice TW: Impact of induction concurrent chemoradiotherapy on pulmonary function and postoperative acute respiratory complications in esophageal cancer. Chest 2005, I 28(I):250-255.

91. Reynolds JV, Ravi N, Hollywood D, Kennedy MJ, Rowley S, Ryan A, Hughes N, Carey M, Byrne P: Neoadjuvant chemoradiation may increase the risk of respiratory complications and sepsis after transthoracic esophagectomy. J Thorac Cardiovasc Surg 2006, I 32(3):549-555.

92. Bosset JF, Gignoux M, Triboulet JP, Tiret E, Mantion G, Elias D, Lozach P, Ollier JC, Pavy JJ, Mercier M, Sahmoud T: Chemoradiotherapy followed by surgery compared with surgery alone in squamous-cell cancer of the esophagus. N Engl J Med 1997, 337(3): $161-167$

93. Heath El, Burtness BA, Heitmiller RF, Salem R, Kleinberg L, Knisely JP, Yang SC, Talamini MA, Kaufman HS, Canto MI, Topazian M, Wu TT, Olukayode K, Forastiere AA: Phase II evaluation of preoperative chemoradiation and postoperative adjuvant chemotherapy for squamous cell and adenocarcinoma of the esophagus. $J$ Clin Oncol 2000, I 8(4):868-876.

94. Kelsen DP, Ginsberg R, Pajak TF, Sheahan DG, Gunderson L, Mortimer J, Estes N, Haller DG, Ajani J, Kocha W, Minsky BD, Roth JA: Chemotherapy followed by surgery compared with surgery alone for localized esophageal cancer. N Engl J Med 1998, 339(27): 1979-1984.

95. Bates BA, Detterbeck FC, Bernard SA, Qaqish BF, Tepper JE: Concurrent radiation therapy and chemotherapy followed by esophagectomy for localized esophageal carcinoma. J Clin Oncol 1996, 14(1): 156-163.

96. Berger AC, Farma J, Scott WJ, Freedman G, Weiner L, Cheng JD, Wang $H$, Goldberg $M$ : Complete response to neoadjuvant chemoradiotherapy in esophageal carcinoma is associated with significantly improved survival. J Clin Oncol 2005, 23( I 9):4330-4337.

97. Carey RW, Hilgenberg AD, Wilkins EW Jr., Choi NC, Mathisen DJ, Grillo HC, Wain JC, Logan DL, Bromberg C: Long-term follow-up of neoadjuvant chemotherapy with 5-fluorouracil and cisplatin with surgical resection and possible postoperative radiotherapy and/or chemotherapy in squamous cell carcinoma of the esophagus. Cancer Invest 1993, I I (2):99-105.

98. Dunne B, Reynolds JV, Mulligan E, Kelly A, Griffin M: A pathological study of tumour regression in oesophageal adenocarcinoma treated with preoperative chemoradiotherapy. I Clin Pathol 200I, 54(I I):84 I-845

99. Suvarna SK, Stephenson T]: A pathological study of tumour regression in oesophageal adenocarcinoma treated with preoperative chemoradiotherapy. J Clin Pathol 2002, 55(9):7I8.

100. Hornick JL, Farraye FA, Odze RD: Prevalence and significance of prominent mucin pools in the esophagus post neoadjuvant chemoradiotherapy for Barrett's-associated adenocarcinoma. Am / Surg Pathol 2006, 30(I):28-35.

I0I. Chirieac LR, Swisher SG, Ajani JA, Komaki RR, Correa AM, Morris JS, Roth JA, Rashid A, Hamilton SR, Wu TT: Posttherapy pathologic stage predicts survival in patients with esophageal carcinoma receiving preoperative chemoradiation. Cancer 2005, I03(7): | 347-1355.

102. Darnton SJ, Allen SM, Edwards CW, Matthews HR: Histopathological findings in oesophageal carcinoma with and without preoperative chemotherapy. I Clin Pathol 1993, 46(I):5 I-55.

103. Mandard AM, Dalibard F, Mandard JC, Marnay J, Henry-Amar M, Petiot JF, Roussel A, Jacob JH, Segol P, Samama G, et al:: Pathologic assessment of tumor regression after preoperative chemoradiotherapy of esophageal carcinoma. Clinicopathologic correlations. Cancer 1994, 73( I I):2680-2686.

104. Swisher SG, Hofstetter W, Wu TT, Correa AM, Ajani JA, Komaki RR, Chirieac L, Hunt KK, Liao Z, Phan A, Rice DC, Vaporciyan AA, Walsh GL, Roth JA: Proposed revision of the esophageal cancer staging system to accommodate pathologic response (pP) following preoperative chemoradiation (CRT). Ann Surg 2005, 24I(5):810-7; discussion 817-20.

105. Chirieac LR, Swisher SG, Correa AM, Ajani JA, Komaki RR, Rashid A, Hamilton SR, Wu TT: Signet-ring cell or mucinous histology after preoperative chemoradiation and survival in patients with esophageal or esophagogastric junction adenocarcinoma. Clin Cancer Res 2005, I I (6):2229-2236.

106. Blazeby JM, Wilson L, Metcalfe C, Nicklin J, English R, Donovan JL: Analysis of clinical decision-making in multi-disciplinary cancer teams. Ann Oncol 2005

107. Stephens MR, Lewis WG, Brewster AE, Lord I, Blackshaw GR, Hodzovic I, Thomas GV, Roberts SA, Crosby TD, Gent C, Allison MC, Shute $\mathrm{K}$ : Multidisciplinary team management is associated with improved outcomes after surgery for esophageal cancer. Dis Esophagus 2006, I 9(3): 164-171.

108. McBroom HM, Ramsay AD: The clinicopathological meeting. A means of auditing diagnostic performance. Am J Surg Pathol I993, I 7(I):75-80

109. Davies AR, Deans DAC, Penman I, Plevris JN, Fletcher J, Wall L, Phillips $H$, Gilmour $H$, Patel D, de Beaux A, Paterson-Brown S: The multidisciplinary team meeting improves staging accuracy and treatment selection for gastro-esophageal cancer. Diseases of the Esophagus 2006, I9(6):496-503.

I 10. Dresner SM, Lamb PJ, Bennett MK, Hayes N, Griffin SM: The pattern of metastatic lymph node dissemination from adeno- 
carcinoma of the esophagogastric junction. Surgery 200I, 129(I):103-109.

III. Thomas P, Doddoli C, Lienne P, Morati N, Thirion X, Garbe L, Giudicelli $R$, Fuentes $P$ : Changing patterns and surgical results in adenocarcinoma of the oesophagus. $\mathrm{Br} J$ Surg 1997, 84(I): II9-125.

I 12. Rice TW, Blackstone EH, Rybicki LA, Adelstein DJ, Murthy SC, DeCamp MM, Goldblum JR: Refining esophageal cancer staging. J Thorac Cardiovasc Surg 2003, I 25(5): I I03-I I I3.

1 13. Sarbia M, Porschen R, Borchard F, Horstmann O, Willers R, Gabbert $H E$ : Incidence and prognostic significance of vascular and neural invasion in squamous cell carcinomas of the esophagus. Int J Cancer 1995, 6I(3):333-336.

114. Theunissen PH, Borchard F, Poortvliet DC: Histopathological evaluation of oesophageal carcinoma: the significance of venous invasion. $\mathrm{Br}$ J Surg 1991, 78(8):930-932.

I 15. Tanaka A, Matsumura E, Yosikawa H, Uchida T, Machidera N, Kubo R, Okuno K, Koh K, Watatani M, Yasutomi M: An evaluation of neural invasion in esophageal cancer. Surg Today 1998, 28(9):873-878.

I16. Griffiths EA, Brummell Z, Gorthi G, Pritchard SA, Welch IM: Tumor length as a prognostic factor in esophageal malignancy: univariate and multivariate survival analyses. J Surg Oncol 2006, 93(4):258-267.

I17. Langley SM, Alexiou C, Bailey DH, Weeden DF: The influence of perioperative blood transfusion on survival after esophageal resection for carcinoma. Ann Thorac Surg 2002, 73(6): I 704- 1709.

I 18. Robey-Cafferty SS, el-Naggar AK, Sahin AA, Bruner JM, Ro JY, Cleary KR: Prognostic factors in esophageal squamous carcinoma. A study of histologic features, blood group expression, and DNA ploidy. Am J Clin Pathol I99I, 95(6):844-849.

119. Roh MS, Lee Jl, Choi PJ: Significance of circumferential resection margin involvement following esophagectomy for esophageal cancer. The Korean Journal of Pathology 2004, 38:23-28.

120. Guidelines for the clinical and pathological studies on carcinoma of the esophagus. Tokyo, Japanese Society for Esophageal Disease; 1999.

121. Ichikura T, Ogawa T, Kawabata T, Chochi K, Sugasawa H, Mochizuki $\mathrm{H}$ : Is adenocarcinoma of the gastric cardia a distinct entity independent of subcardial carcinoma? World J Surg 2003, 27(3):334-338.

Publish with Bio Med Central and every scientist can read your work free of charge

"BioMed Central will be the most significant development for disseminating the results of biomedical research in our lifetime. "

Sir Paul Nurse, Cancer Research UK

Your research papers will be:

- available free of charge to the entire biomedical community

- peer reviewed and published immediately upon acceptance

- cited in PubMed and archived on PubMed Central

- yours - you keep the copyright
BioMedcentral 